\title{
Impact Of the Quality of Hospitality Services on Customer Satisfaction - Kosovo Case Study
}

\author{
Valbona ZEQIRAJ ${ }^{1 *}$, Artan NIMANI² \\ ${ }^{1}$ Assistant Professor, University of Gjilan” Kadri Zeka", Kosovo, Email: valbona.zeqiraj@uni-gjilan.net, \\ ${ }^{2}$ Assistant Professor, University of Gjakova “FehmiAgani', Kosovo, Email: artan.nimani@uni-gjk.org \\ ${ }^{*}$ Corresponding Author
}

\author{
Received: 09.11.2021 Accepted: 11.12.2021 $\quad$ Published: 01.02.2022 $\quad$ DOI: 10.47750/QAS/23.186.14
}

\begin{abstract}
The increased significance of the service sector to the global economy has led to a heightened concern regarding the quality of services being offered. The concept of quality and its relationship with the service industries has become a major preoccupation of any service sector, not least the hospitality industry. The purpose of this paper is to determine the impact of the quality of hospitality services in Kosovo on customer satisfaction and their loyalty. This paper uses primary data obtained through a survey of customers of hospitality services in Kosovo. The survey questionnaire consisted of closed-ended questions with pre-given answers from which the respondents had to choose the answer that best represented their views. In order to determine the impact of the quality of catering services on customer satisfaction and their loyalty to the hospitality facility, cross-tabular analyzes of certain issues were performed, calculating the coefficient of determination and the correlation coefficient. Regression is the most appropriate tool because it enables the establishment of the relationship between two or more variables (direction and strength of the relationship between the independent variables and the dependent variable). As a result of the conducted research it can be concluded that the quality of hospitality products and services in Kosovo is at a satisfactorily high level. This results in high satisfaction of consumers of hospitality services in Kosovo. Because consumers are satisfied with the catering services in Kosovo, they most often visit the hospitality facilities whose quality of services they are already convinced of, i.e. they are loyal consumers of certain hospitality facilities. The result in the research shows a strong direct relationship between the quality of hospitality services in Kosovo and consumer loyalty. In order to maintain their competitive advantage, retain loyal customers and increase their consumption as well as financial results, hospitality establishments in Kosovo should continue to provide high quality of their products and services in the future.
\end{abstract}

Keywords: quality, hospitality services, consumer, satisfaction, loyalty, Kosovo.

\section{Introduction}

The increased significance of the service sector to the global economy has led to a heightened concern regarding the quality of services being offered. The concept of quality and its relationship with the service industries has become a major preoccupation of any service sector, not least the hospitality industry. However, the specific characteristics of the hospitality industry make the process of measuring the quality of services in this activity even more difficult. In the hospitality industry, customers rarely consume pure products but a mixture of products and services. Therefore, the consumer experience in the hospitality industry is a combination of tangible and intangible experience. A successful hospitality business does not only count on its products and services, but also how they are delivered. The qualities of staff and the way they deliver the service are often more important than the tangible products in making a hospitality experience satisfactory or unsatisfactory. Hence, the two features can contribute to the total experience in the service delivery process.

Customers are very crucial part of the success of any company. Their satisfaction with a purchased product or service influences their decision to purchase it again. Customer satisfaction leads to repeat purchases, loyalty and to retain customers. They will also tend to say good things and to recommend the product or service to other consumers. Customer satisfaction is the outcome of customer's perception of the value received in a transaction or relationship, where value equals perceived service quality, compared to the value expected from transactions or relationships with competing vendors.

In order to achieve customer satisfaction, it is important to recognize and to anticipate customers' needs and to be able to satisfy them. Companies which are able to rapidly understand and satisfy customers' needs, make greater profits than those which fail to understand and satisfy them.

In the majority of studies, perceptions of service quality and value have been found to affect satisfaction, and satisfaction consequently affects loyalty and post-behaviors of consumers. Loyalty is very closely related to the future behavior of the consumer and it is measured through both the intention to return and the recommendation to others. 


\section{GENERAL MANAGEMENT}

\section{Literature Review}

\subsection{Service Quality}

There are a number of different definitions of quality. No definition of quality can be said to be the best. Each definition has its strengths and weaknesses arising from the relevant situation and from the criteria of measurement, generalization, managerial benefit and relevance to consumers. Different definitions of quality are appropriate under different circumstances.

Thus, quality has been defined as excellence (Tuchman, 1980), value (Feigenbaum1951), conformance to specifications (Shewhart, 1931; Levitt, 1972), conformance to requirements (Crosby, 1979), fitness for use (Juran, 1974; 1988), product desirable attributes (Leffler, 1982), loss avoidance (Taguchi, 1987) and meeting customer expectations (Ryall and Kruithof, 2001; ISO 9000, 2005) etc.

David Garvin classifies all definitions of quality into 5 groups:

- transcendent approach

- product-based approach

- user-based approach

- manufacturing-based approach

- value approach.

According to the transcendent approach, quality is a mark of uncompromising standards, i.e. a synonym for innate perfection, absolute and universally recognizable and it refers only to those products and services that achieve the highest standards.

The emphasis in the product-based approach is on quality as a precise and measurable variable. This approach leads to vertical or hierarchical ordering of quality. According to this approach, differences in products quality are due to differences in the quantity of some ingredient or attribute that the products possess.

According to the consumer-based approach, the quality of the product or service depends on the subjective views and perceptions of the consumer himself. For every consumer, the best quality has the product or service that best and most fully satisfies his needs and requirements. In this case, quality is equated with consumer satisfaction.

The manufacturing-based approach focuses on internal matters. According to this approach, the products are designed and manufactured according to predetermined specifications, and after they are produced, deviations from the specifications are detected through quality control techniques. Also, in the service organizations, there may be certain specifications that will relate to the services.

The value approach analyzes the quality of the product / service in relation to the price. According to this approach, quality is the ratio between the value obtained by purchasing a product / service and the price paid to purchase that product / service. Therefore, a higher price would mean higher quality and lower price/lower quality.

Determining the quality of services is much more difficult than determining the quality of products due to the four specific characteristics of the services:

- Intangibility - services cannot generally be seen, tasted, felt, heard or smelled before being consumed. The potential customer is often unable to perceive the service before the service delivery.

- Inseparability - Whereas goods are first produced, then stored and finally sold and consumed, the process of production and sale of services take place simultaneously and are inseparable from each other.

- Variability (or heterogeneity) - An unavoidable consequence of simultaneous production and consumption is variability in performance of a service.
The quality of the service may vary depending on who provides it, as well as when and how it is provided.

- Perishability - As services are performances they cannot be stored for later sales or use. If demand far exceeds supply it cannot be met, as in manufacturing, by taking goods from a warehouse. Equally, if capacity far exceeds demand, the revenue and/or value of that service is lost.

The term 'Service quality' is harder to define and judge. Number of authors tried to define it and give definitions in different point of views.

Philip Kotler and Gary Armstrong defined the term 'service quality' as the ability of a service firm to hang on to its customer. According to them, customer retention is the best measure of service quality.

Service quality is the ability of an organization to meet the needs, wants, and expectations of the customer (Albrecht \& Zemke, 2002; Edvardsson, Thomasson, \& Ovretveit, 1994; Martin, 2003).

According to Zeithaml et al. (2006) service quality from the user's perspective is defined as consistently meeting or exceeding the customer expectations.

Parasurman.et al, 1988) demonstration that service quality is the difference between the expected service and perceived service.

The client is the only person who can determine and evaluate the quality of service he receives based on his personal preferences, expectations and experiences. On the other hand, the quality of services is especially important for service providers because it provides them with a sustainable competitive advantage, increased service sales, higher profitability and loyal customers.

Parasurman, Zeithaml and Berry (1988) listed five dimensions for determining the quality of services.

Those dimensions are as follows:

- Reliability - the ability to perform the promised service dependably and accurately. It is regarded as the most important determinant of perceptions of service quality.

- Responsiveness - the willingness to help customers and to provide prompt service. This dimension is particularly prevalent where customers have requests, questions, complaints and problems.

- Assurance - the employees' knowledge and courtesy, and the ability of the service to inspire trust and confidence.

- Empathy - the caring, individualized attention the service provides its customers.

- Tangibles - the appearance of physical facilities, equipment, personnel and communication materials. All of these are used in varying degrees to project an image that will find favor with consumers.

\subsection{Consumer Satisfaction}

The term satisfaction is of Latin origin and comes from the words "satis" (enough) and "facere" (to do).

Lovelock and Wirtz (2011) defined customer satisfaction as "a short-term emotional reaction to a specific service performance."

Kotler (2003) defines customer satisfaction as "a person's feeling of pleasure or disappointment resulting from comparing a product's perceived performance (or outcome) in relation to his or her expectation".

Pizam and Ellis (1999) stated that customer satisfaction is a psychological concept that includes the feeling of happiness and pleasure that results from gaining what one hopes for and expects from an pleasing product and service. 


\section{GENERAL MANAGEMENT}

Cardozo (1965) suggested that satisfaction happen when consumers either authorize their pre-purchase opportunities for an obtained service or completely surpass their expectations about purchased services.

Value is the driver of consumer satisfaction. Satisfaction is the consumer's perception of the value he received by purchasing a particular product or service compared to the price he paid for purchasing that product or service. Satisfaction is a feeling that occurs in the phase after the purchase and consumption of products and the use of services by consumers.

In order for a feeling of satisfaction to appear among the consumers, it is necessary to at least meet the expectations of the consumers and, if possible, to exceed those expectations. Consumers form certain expectations before buying products and services. These expectations may be related to the nature and performance of the product or service, the price of the product or service and the efforts that precede the immediate benefits of the product or service and the direct benefits or costs for consumers. Expectations are based on previous experiences, opinions of family, friends, as well as information and promises of promotional tools of companies. If the product / service meets the expectations of consumers, consumers will be satisfied and vice versa, if it does not meet the expectations of consumers, they will be dissatisfied. Consumer dissatisfaction is based on the statement that by purchasing a particular product or service, he received less than expected, which is called a negative confirmation (fulfillment) of the assumption. The highest degree of satisfaction implies the admiration of the consumer. Satisfaction can be manifested as excitement if the characteristics of products and services significantly exceed consumer expectations. The extent to which a neutral consumer attitude will turn into satisfaction or dissatisfaction depends of the degree (level) of consumer expectations and product performance.

Delivery value is monitored through two dimensions effectiveness and efficiency.

Effectiveness refers to the degree to which the product / service meets the needs and desires of the consumer, and efficiency at the lowest possible cost (expressed in money, effort and time).

In order to create and deliver value to the consumer, the company has to insert notable attributes and elements into its offer (product / service). These can be: quality improvement, innovation, adapting products / services to specific customer requirements, warnings and warranties, etc. Values are also achieved through pricing policy, payment terms, exclusive offer, personal communication, etc. From the consumer's point of view, the delivered value is defined as the difference between the expected value of the product or service and the total costs incurred in requesting, purchasing and using that product / service.

Consumer satisfaction with the purchased products or services has two main benefits: increased consumer loyalty to a particular company and positive oral propaganda or positive publicity. Positive publicity is a very effective way of acting in reference groups (family, friends, etc.) which leads to an increase in the number of new customers of the particular company (catering facility). The company's goal is to increase customer satisfaction and to offer greater value in using products and services. It is also profitable for the company itself because maintaining a market position is more easily achieved by changing quality than by relatively changing prices.

\section{Methodology}

This paper uses primary data obtained through a survey of 100 customers of hospitality services in Kosovo of which 75 are male and 25 female. The survey questionnaire consisted of 9 closed-ended questions. From the answers given to each question, they had to note only one answer that best suited their views. In order to determine the impact of the quality of catering services on customer satisfaction and their loyalty to the hospitality facility, cross-tabular analyzes of certain issues were performed, calculating the simple linear regression and the correlation coefficient. Based on that, certain conclusions are derived.

\section{Results}

This part of the paper refers to the questions intended for the respondents and analysis of their answers. The questions refer to the quality of the hospitality products and services, the value obtained for the paid price, the remarks by the consumers regarding the hospitality offer, the way of choosing the hospitality facility and the satisfaction of the consumers from the catering services in Kosovo.

\begin{tabular}{|l|l|l|l|l|}
\hline & Frequency & Percent & Valid Percent & Cumulative percent \\
\hline I am very satisfied & 35 & 35.00 & 35.00 & 35.00 \\
\hline I'm satisfied & 50 & 50.00 & 50.00 & 85.00 \\
\hline Neither satisfied nor dissatisfied & 10 & 10.00 & 10.00 & 95.00 \\
\hline I am dissatisfied & 5 & 5.00 & 5.00 & 100.00 \\
\hline I am very dissatisfied & 0 & 0.00 & 0.00 & 100.00 \\
\hline Total & 100 & 100.00 & 100.00 & \\
\hline
\end{tabular}

Table 1: How satisfied are you with the hospitality services in Kosovo? Source: Author's own calculations

Majority of surveyed consumers (85\%) are satisfied with the hospitality services in Kosovo (very satisfied 35\% and satisfied $50 \%$ ). It is followed by the category of consumers who answered that they are neither satisfied nor dissatisfied with the hospitality services in Kosovo (10\%), and last is the category of consumers who are not satisfied with the hospitality services in Kosovo (only $5 \%$ ). (Table 1 ) 


\section{GENERAL MANAGEMENT}

\begin{tabular}{|l|l|l|l|l|}
\hline & Frequency & Percent & Valid percent & Cumulative percent \\
\hline Very high quality & 40 & 40.00 & 40.00 & 40.00 \\
\hline high quality & 55 & 55.00 & 55.00 & 95.00 \\
\hline Low quality & 5 & 5.00 & 5.00 & 100.00 \\
\hline Very low quality & 0 & 0.00 & 0.00 & 100.00 \\
\hline Total & 100 & 100.00 & 100.00 & \\
\hline
\end{tabular}

Table 2: How do you assess the quality of hospitality products and services in Kosovo?

Source: Author's own calculations

When asked how they evaluate the quality of hospitality products and services in Kosovo, the majority of respondents $(55 \%)$ answered that hospitality products and services are of high quality. In second place is the category of consumers who believe that hospitality products and services in Kosovo are of very high quality $(40 \%)$, followed by consumers who believe that products and services are of low quality (5\%). (Table 2$)$

\begin{tabular}{|l|l|l|l|l|}
\hline & Frequency & Percent & Valid Percent & Cumulative percent \\
\hline Yes, they fully meet my expectations & 45 & 45.00 & 45.00 & 45.00 \\
\hline Yes, they meet my expectations & 50 & 50.00 & 50.00 & 95.00 \\
\hline They do not meet my expectations & 5 & 5.00 & 5.00 & 100.00 \\
\hline They do not meet my expectations at all & 0 & 0 & 0 & 100.00 \\
\hline Total & 100 & 100.00 & 100.00 & \\
\hline
\end{tabular}

Table 3: Do hospitality services in Kosovo meet your expectations? Source: Author's own calculations

Even $95 \%$ of consumers surveyed believe that hospitality services in Kosovo meet their expectations in terms of quality ( $45 \%$ of consumers answered that hospitality services fully meet their expectations, and $50 \%$ answered that they meet their expectations). Only $5 \%$ of surveyed consumers answered that the quality of hospitality services does not meet their expectations. (Table 3)

\begin{tabular}{|l|l|l|l|l|}
\hline & Frequency & Percent & Valid Percent & Cumulative percent \\
\hline YES & 95 & 95.00 & 95.00 & 95.00 \\
\hline NO & 5 & 5.00 & 5.00 & 100 \\
\hline Total & 100 & 100 & 100 & \\
\hline
\end{tabular}

Table 4: Do you get the value for the price you paid in the hospitality facilities in Kosovo? Source: Author's own calculations

Even $95 \%$ of the total surveyed consumers in Kosovo believe that they received the value for the price they paid for the products and services in the hospitality facilities, and only
$5 \%$ believe that they did not receive the appropriate value for the product or service for the price they paid. (Table 4)

\begin{tabular}{|l|l|l|l|l|}
\hline & Frequency & Percent & Valid Percent & Cumulative Percent \\
\hline YES & 90 & 90.00 & 90.00 & 90.00 \\
\hline NO & 10 & 10.00 & 10.00 & 10.00 \\
\hline Total & 100 & 100 & 100 & \\
\hline
\end{tabular}

Table 5: Do you think that the hospitality facilities in Kosovo create and modify the offer in accordance with the requirements of the consumers?

Source: Author's own calculations

$90 \%$ of consumers believe that hospitality facilities in Kosovo create and modify their offer in accordance with the requirements of consumers, and $10 \%$ of surveyed consumers do not agree with this statement. (Table 5)

\begin{tabular}{|l|l|l|l|l|}
\hline & Frequency & Percent & Valid Percent & Cumulative percent \\
\hline $\begin{array}{l}\text { I mostly go to a hospitality facility whose } \\
\text { quality of services I am convinced of }\end{array}$ & 75 & 75.00 & 75.00 & 75.00 \\
\hline $\begin{array}{l}\text { On the recommendation of relatives and } \\
\text { friends }\end{array}$ & 10 & 10.00 & 10.00 & 85.00 \\
\hline $\begin{array}{l}\text { Based on the rating from other } \\
\text { consumers on social networks }\end{array}$ & 8 & 8.00 & 8.00 & 93.00 \\
\hline Based on advertisement & 7 & 7.00 & 7.00 & 100.00 \\
\hline Total & 100 & 100.00 & 100.00 & \\
\hline
\end{tabular}

Table 6: How do you choose the hospitality facility where you use a certain service? Source: Author's own calculations 


\section{GENERAL MANAGEMENT}

When consumers choose the hospitality facility (restaurant) in which they will use certain services, they usually choose the hospitality facility whose quality of services they are already convinced of, which means that they are loyal consumers of a certain hospitality facility (thanks to the quality of the products and services they receive in it) and are frequent guests in it ( $75 \%$ of surveyed consumers). In the second place is the category of consumers who choose a hospitality facility on the recommendation of relatives and friends (10\%), followed by those consumers who choose the hospitality facility based on the rating given by other consumers on social networks ( $8 \%$ ), and the last place is taken by the consumers who, when choosing the catering facility, are guided by the seen advertisement (7\%). (Table 6)

\begin{tabular}{|l|l|l|l|l|}
\hline & Frequency & Percent & Valid Percent & Cumulative Percent \\
\hline $\begin{array}{l}\text { The quality of products and } \\
\text { services is low }\end{array}$ & 3 & 3.00 & 3.00 & 3.00 \\
\hline Prices are too high & 10 & 10.00 & 10.00 & 13.00 \\
\hline Hygiene is very low & 4 & 4.00 & 4.00 & 17.00 \\
\hline The staff is impolite & 1 & 1.00 & 1.00 & 18.00 \\
\hline The service is slow & 7 & 7.00 & 7.00 & 25.00 \\
\hline No, I have no remarks & 75 & 75.00 & 75.00 & 100.00 \\
\hline Total & 100 & 100 & 100 & \\
\hline
\end{tabular}

Table 7: Do you have any remarks regarding the hospitality offer in Kosovo?

Source: Author's own calculations

Most of the respondents $(75 \%)$ have no remarks regarding catering services in Kosovo. However, some respondents $(10 \%)$ think that the prices of products and services are too high, others claim that the hygiene in the catering facilities is at a very low level (4\%), the third group states the slow service as a weakness $(7 \%)$, and the rest cite the poor quality of products and services as the main remark about the catering facilities in Kosovo (3\%) and the rudeness of the staff (1\%). (Table 7)

\begin{tabular}{|l|l|l|l|l|}
\hline & Frequency & Percent & Valid Percent & Cumulative Percent \\
\hline Yes, often & 3 & 3.00 & 3.00 & 3.00 \\
\hline Yes, sometimes & 10 & 10.00 & 10.00 & 13.00 \\
\hline Just once & 7 & 7.00 & 7.00 & 20.00 \\
\hline No, never & 80 & 80.00 & 80.00 & 100.00 \\
\hline Total & 100 & 100 & 100 & \\
\hline
\end{tabular}

Table 8: Have you ever had a complaint about the hospitality products or services in Kosovo? Source: Author's own calculations

The majority of respondents $(80 \%)$ in Kosovo have never had any remarks regarding catering services. Some respondents $(10 \%)$ sometimes had a remark, $7 \%$ stated that they had a remark only once in a catering facility, and $3 \%$ of consumers have frequent remarks about the catering services in Kosovo. (Table 8)

\begin{tabular}{|l|l|l|l|l|}
\hline & Frequency & Percent & Valid percent & Cumulative Percent \\
\hline By providing an additional free product or service & 4 & 4.00 & 4.00 & 4.00 \\
\hline By giving a discount in the price & 6 & 6.00 & 6.00 & 10.00 \\
\hline By replacing the product or service & 50 & 50.00 & 50.00 & 60.00 \\
\hline With an apology from the employee & 27 & 27.00 & 27.00 & 87.00 \\
\hline With an apology from the manager & 10 & 10.00 & 10.00 & 97.00 \\
\hline $\begin{array}{l}\text { There was no feedback at all from the employee } \\
\text { and the manager (the problem was not solved) }\end{array}$ & 3 & 3.00 & 3.00 & 100.00 \\
\hline Total & 100 & 100 & 100 & \\
\hline
\end{tabular}

Table 9: If you had any complaints, how did the manager or employee solve the problem? Source: Author's own calculations

The most commonly used strategy for resolving complaints and remarks made by consumers of catering services in Kosovo, by employees and managers is the replacement of the product or service with new similar products or services $(50 \%)$, followed by: apologies from the employee (27\%), an apology from the manager of the catering facility (10\%), giving a discount in the price $(6 \%)$ and giving an additional free product or service $(4 \%)$. But $3 \%$ of the surveyed consumers stated that there was no feedback at all on their complaint by the employee and the manager of the catering facility, so the problem was not solved at all. (Table 9)
In order to examine the impact of the quality of services in hospitality on consumer satisfaction in Kosovo, crossexamination of questions 2 and 1 was performed, calculating the coefficient of determination and the correlation coefficient that determine the strength and direction of interdependence of the two variables being analyzed.

For this purpose, the following basic research hypothesis was tested:

$\mathrm{HO}$ : There is no a significant relationship between the quality of hospitality products and services in Kosovo and consumer satisfaction.

$\mathrm{H} 1$ : There is a significant relationship between the quality of 


\section{GENERAL MANAGEMENT}

hospitality products and services in Kosovo and consumer satisfaction.
The following results were obtained as a result of the regression analysis (Table 10$)$.

\begin{tabular}{|l|l|l|l|l|l|}
\hline & DF & Sum of Square & Mean Square & F Statistic & P value \\
\hline Regression & 1 & 48.2462 & 48.2462 & $325.9918(1.98)$ & 0 \\
\hline Residual & 98 & 14.5038 & 0.148 & & \\
\hline Total & 99 & 62.75 & 0.6338 & & \\
\hline
\end{tabular}

Table 10: Regression ANOVA

Source: Author's own calculations

Coefficient of determination R2 $=0.7689$

Coefficient of correlation $r=0.8768$

Overall regression: right-tailed, $F(1,98)=325.9918$

$\beta=1.21$

Covariance $=0.4015$

$\mathrm{p}<0.001$ Since $\mathrm{p}$-value $<\alpha(0.05)$, we reject the $\mathrm{HO}$.

Regression line equation $Y=-0.1527+1.2137 X$

The coefficient of determination $\mathrm{R} 2$ is 0.7689 . It means that $76.89 \%$ of the variability of $Y$ (satisfaction of consumers in hospitality in Kosovo) is expained by $X$ (quality of hospitality services in Kosovo). The variable hospitality services quality had a beta value of 1.21 and it was a significant at $p<\alpha(0.05)$ significance level. These finding indicate that there is very strong evidence to reject the null hypothesis and support the basic research hypothesis. The positive relationship between hospitality services quality in Kosovo and consumer satisfaction was strengthened by the very strong direct relationship between these two variables, a Pearson coefficient of $r=0.8768$ with $p$ value less than 0.001 . So, there is a significant and positive relationship between the hospitality services quality in Kosovo and consumer satisfaction.

In order to determine the impact of the quality of hospitality services in Kosovo on customer loyalty, questions 2 (about quality of hospitality services in Kosovo) and 6 (loyalty of customers) were crossed and the coefficient of determination and the correlation coefficient were calculated.

For this purpose, the following alternative hypothesis was tested:

$\mathrm{HO}$ : There is no a significant relationship between the quality of hospitality services in Kosovo and consumer loyalty.

$\mathrm{H} 1$ : There is a significant relationship between the quality of hospitality services in Kosovo and consumer loyalty.

The following results were obtained as a result of the regression analysis (Table 11 ).

\begin{tabular}{|l|l|l|l|l|l|}
\hline & DF & Sum of Square & Mean Square & F Statistic & P value \\
\hline Regression & 1 & 11.9298 & 11.9298 & $56.1534(1.98)$ & $3.008 \mathrm{e}-11$ \\
\hline Residual & 98 & 20.8202 & 0.2125 & & \\
\hline Total & 999 & 32.75 & 0.3308 & & \\
\hline
\end{tabular}

Table 11. Regression ANOVA

Source: Author's own calculations

Coefficient of determination $\mathrm{R} 2=0.3643$

Coefficient of correlation $r=0.6035$

Overall regression: right-tailed, , $F(1,98)=56.1534$

Covariance $=0.3177$

$\beta=0.96$

$\mathrm{p}$-value $=3.003 \mathrm{e}-11 \mathrm{p}$-value $<0.00001$ The result is significant at $p<\alpha(0.05)$

Regression line equation $Y=-0.1145+0.9603 X$

The coefficient of determination $\mathrm{R} 2$ is 0.3643 . It means that $36.43 \%$ of the variability of $Y$ (loyalty of customers in hospitality industry in Kosovo) is expained by $X$ (quality of hospitality services in Kosovo). The variable hospitality services quality had a beta value of 0.96 and it was a significant at $p<\alpha(0.05)$ significance level. These finding indicate that there is very strong evidence to reject the null hypothesis and support the alternative hypothesis. The positive relationship between hospitality services quality in Kosovo and consumer loyalty was strengthened by the strong direct relationship between these two variables, a Pearson coefficient of $r=0.6035$ with $p$ - value less than 0.00001 . So, there is a significant and strong positive relationship between the hospitality services quality in Kosovo and consumer loyalty.

\section{Discussion}

Based on the conducted research it can be concluded that there is a very strong direct relationship between quality of hospitality services in Kosovo and satisfaction of customers in hospitality in Kosovo.
Also, there is a strong direct relationship between quality of hospitality services in Kosovo and loyalty of customers in hospitality in Kosovo.

Most of the respondents $(75 \%)$ have no remarks regarding catering services in Kosovo. However, some respondents $(10 \%)$ think that the prices of hospitality products and services are too high, others claim that the hygiene in the catering facilities is at a very low level (4\%), the third group states the slow service as a weakness $(7 \%)$, and the rest cite the poor quality of products and services as the main remark about the catering facilities in Kosovo (3\%) and the rudeness of the staff $(1 \%)$.

The majority of respondents in Kosovo (80\%) have never had any remarks regarding catering services. The most commonly used strategy for resolving complaints and remarks of consumers of catering services in Kosovo, by employees and managers is the replacement of the product or service with new similar products or services (50\%), followed by: apologies from the employee $(27 \%)$, an apology from the manager of the catering facility $(10 \%)$, giving a discount in the price $(6 \%)$ and giving an additional free product or service (4\%).

\section{Conclusions and Recommendation}

The quality of hospitality products and services in Kosovo is at a satisfactorily high level. There is existence of a very high direct relationship between the quality of hospitality services and customer satisfaction in Kosovo. Because they are satisfied with the catering services, the consumers in Kosovo most often 


\section{GENERAL MANAGEMENT}

visit the hospitality facilities whose quality of services they are already convinced of, i.e. they are loyal consumers of certain hospitality facilities. The result in the research shows a strong direct relationship between the quality of hospitality services in Kosovo and consumer loyalty.

Therefore, the recommendations for managers and employees of hospitality facilities in Kosovo are the following: in order to maintain the competitive advantage, retain loyal customers and increase their consumption as well as financial results, they should:

- continue to provide high quality of their products and services in the future,

- $\quad$ try to exceed consumer expectations, not just meet them,

- explore the target market and offer products and services in accordance with the needs and requirements of the market,

- create and modify the offer in accordance with the requirements of the consumers,

- successfully and well solve the problems with the guests,

- $\quad$ minimize mistakes and omissions in their work.

\section{References}

[1] Bytyqi, B., Rustemi, P., Thairi, A., and Kovaci, I. (2021). Thi importance of Sustainable Development of Travel and Tourism Industry in the Turnover of Foreign Visitors: The Case of Kosovo. International Journal of Economics and Business Administration LIEBA, Volume IX, Issue 2.

[2] Borovci, B., Tahiri, A., and Kovaci, I. (2021). Consumer Behavior towards the Touris Offer in Kosovo - with a Focus on the Development of Mountain Tourism. International Journal of Innovative Science and Research Technology, Vol. 6, Issue 2.

[3] Brown, S.W. et al. (1991). Service Quality - Multidisciplinary and Multinational Perspectives. Lexington Books.

[4] Collis, J., Hussey, R. (2013). Business Research: A Practical Guide for Undergraduate and Postgraduate Students. Macmillan International Higher Education. New York. USA. ISBN 978-0-230-30183-2.

[5] Gilmore, A. (2003). Service Marketing and Management. SAGE Publication.

[6] Gemkow, W. ( 2010 ). An Investigation of Service Quality in Upscale Hotels Using the Critical Incident technique. GRIN Verlag.

[7] Hill, N., and Brierley, J. (2017). How to Measure Customer Satisfaction. Second edition. Routledge.

[8] Hill, N., Roche, G., and Allen, R. (2007). Customer Satisfaction: The Customer Experience Through The Customer's Eyes. Cogen Publishing Ltd.
[9] Hill, N., and Alexander, J. (2006). Handbook of Customer Satisfaction and Loyalty Measurement - Third Edition. Gower Publishing Limited.

[10] Kandampully, J. et al. (2009). Service Quality Management in Hospitality, Tourism and Leisure. Routledge.

[11] Kovaci, I. Tahiri, A., and Bushi, F. (2020). Travel and Tourism Industry Development - The Case of Kosovo. Analele Universitati din Oradea, Seria geografie, XXX, No.2.

[12] Mayabi, B. (2018). Satisfying the Customer -Quality Management and Service. GRIN Verlag.

[13] Pakurar, M. et al. (2019). The Service Quality Dimensions that Affect Customer Satisfaction in the Jordanian Banking Sector. Sustainability. 2019, 11, 1113; doi:10.3390/su11041113. MDPI.

[14] Parasuraman, A., Zeithaml, V.A., Berry, L.L. (1985). A conceptual model of service quality and its implications for future research. Cross Ref.

[15] Parasuraman, A., Zeithaml, V.A., Berry, L.L.(1988). Servqual: A multiple-item scale for measuring consumer perc.

[16] Parasuraman, A., Berry, L.L., Zeithaml, V.A. (1991) Understanding customer expectations of service. Sloan Manag. Rev.

[17] Poor, M. H., Poor, M. A. and Darkhaneh, M. A. (2013). The Quality in Service and Its Importance in Service Organizations. Arabian Journal of Business and Management Review (OMAN Chapter) Vol. 3, No.3.

[18] Rosander, A.C. (1985). Applications of Quality Control in the Service Industries. ASQC Quality Press.

[19] Strawderman, L. and Koubek, R. (2008). Human Factors and Usability in Service Quality Measurement. Human Factors and Ergonomics in Manufacturing, Vol. 18 (4) 454-463. Wiley Periodicals, Inc.

[20] Sunder, V. K. (2009). Outsourcing and Customer Satisfaction.

[21] Tahiri, A., Kovaci, I., Lekiqi, B., and Rexhepi, A. (2021). Tourism and Hotel Industry: Definition, Concepts and Development: The Case of Kosovo. Quality Access to Success. Vol. 22, No.182

[22] Tahiri, A. and Kovaci, I. (2017). Assessment of the quality of product in tourism. European Journal of Multidisciplinary Studies. Vol.2, Issue 5 .

[23] Tahiri, A., Kovaci, I., and Bushi, F. (2020). Analyzing Hotel Management from the Perspective of Management and Employees and Their Impact on Tourist Satisfaction with Hote Services in Kosovo. ACTA UNIVERSITATIS DANUBIUS ECONOMICA, Vol. 16, No.1.

[24] Yarimogly, E. K. (2014). A Review on Dimensions of Service Quality Models. Journal of Marketing Management. Vol. 2, No. 2, pp. 79-93. ISSN: 2333-6080 (Print), 2333-6099 (Online). Published by American Research Institute for Policy Development.

[25] Wilson, A. et al. (2021). Services Marketing - Integrating Customer Focus Across the Firm. Fourth Edition, McGraw Hill. 